\title{
EFFECT OF ESSENTIAL OILS ON THE MYCELIAL GROWTH OF Pythium sp. CAUSAL AGENT OF DAMPING OFF IN LETTUCE
}

\author{
Gabriel Ferreira Paiva ${ }^{1}$, Tayane Patrícia de Oliveira Malanski Barbieri² ${ }^{2}$ Bruna da Silva Melo², \\ Francisco José Teixeira Gonçalves ${ }^{2}$, Mateus Augusto Donegá \\ ${ }^{1}$ Universidade Federal de Viçosa, Viçosa, Minas Gerais State, Brazil \\ E-mail: gabrielfpaiva2009.gf@gmail.com \\ ${ }^{2}$ Instituto Federal de Mato Grosso do Sul, Nova Andradina, Mato Grosso do Sul State, Brazil \\ E-mail: tayane.oliveira@ novaandradina.org, brunas.mello@ hotmail.com,goncalvesfj@yahoo.com.br, \\ mateus.donega@ifms.edu.br
}

\begin{abstract}
This work aims to test the antifungal effect of essential oils of Corymbia citriodora, Mentha spicata and Mentha arvensis in vitro. The study was carried out in a completely randomized block design, with a factorial scheme of three essential oils (Corymbia citriodora, Mentha spicata e Mentha arvensis) and five concentrations, of 0, 50, 100, 500 and $1000 \mathrm{mg} \mathrm{ml}^{-1}$. It was possible to conclude that the tested oils have compounds effective in inhibiting the mycelial growth of Pythium sp., suggesting the possibility of use for the formulation of biofumigants for soil treatment.
\end{abstract}

Keywords: Tipping, alternative control, Corymbia citriodora, Mentha spicata, Mentha arvensis

\section{EFEITO DE ÓLEOS ESSENCIAIS SOBRE O CRESCIMENTO MICELIAL DE Pythium sp. AGENTE CAUSAL DE DAMPING OFF EM ALFACE}

\section{RESUMO}

Este trabalho teve como objetivo testar o efeito antifúngico dos óleos essenciais de Corymbia citriodora, Mentha spicata e Mentha arvensis in vitro. O estudo foi realizado em delineamento experimental de blocos inteiramente casualizados, com esquema fatorial 3x5 sendo três óleos essenciais (Corymbia citriodora, Mentha spicata e Mentha arvensis) e cinco concentrações $\left(0,50,100,500\right.$ e $\left.1000 \mathrm{mg} \mathrm{ml}^{-1}\right)$. Foi possível concluir que os óleos testados possuem compostos efetivos na inibição do crescimento micelial de Pythium sp., sugerindo a possibilidade de uso para a formulação de biofumigantes para tratamento de solo.

Palavras-chave: Tombamento, controle alternativo, Corymbia citriodora, Mentha spicata, Mentha arvensis 


\section{INTRODUCTION}

Pythium genus is the most common and most destructive causal agent associated with seedling tipping, also called damping off and root rot in all types of cultivated plants. Damping off results from rotting in the basal region of the stem in the juvenile phase, the damage begins to occur even before the somatic structures of the pathogen penetrate the tissue, through the action of enzymes. In addition to root rot, the disease also affects seeds, mainly in the germination phase, attacking the seedling tenderest organs and causing it to tip over. The damage is divided into two types: damage being caused to the parts of the plant in contact with the soil and the parts of the plant that are above the ground. Because it is a soil pathogen and because it has resistance structures called oospores that are present when the infested area does not have seedlings to cause infection, its control is difficult (AGRIOS, 2005; ZAMBOLIM \& JESUS JÚNIOR, 2012).

Currently the control of this pathogen is carried out through physical methods, with the use of steam and chemicals with the use of fumigation. However, the indiscriminate use of these products has been causing several problems such as food residues, contamination of soils and groundwater, intoxication of rural workers and also reducing the population of microorganisms affecting the biological balance of the soil, making it more susceptible to reinfestation and infestation by other pathogens. Therefore, these products have undergone great resistance by the society, which has motivated the search for new molecules that can be used to control diseases.

Among the products studied, essential oils have been attracting the attention of researchers, as they are products easily found in nature and also because they are highly volatile, reducing their time in the environment. (CAMPANOLA \& BETTIOL, 2003; SOUSA et al., 2012). Essential oils are aromatic compounds and their extraction is mainly carried out by steam distillation technique. Extraction can be performed from roots, stems, leaves and flowers (TRANCOSO, 2013). The effect of essential oils is mainly attributed to the presence of major compounds, that is, those that are found in a higher percentage in the essential oil.

Currently, several studies have demonstrated the antifungal action of essential oils. Medeiros et al. (2016) tested the essential oils of Lippia origanoides, L. lacunosa and Syzygium aromaticum against the fungi Gloeophyllum trabeum and Trametes versicolor that cause damage to wood. Their results showed that in some cases essential oils showed superior inhibition results when compared with a commercial fungicide. El Ouadi et al. (2017) used the essential oil of Melissa officinalis to control the fungi Botrytis cinerea, Penicillium expansum and Rhizopus 
stolonifer that cause losses of apples in the post-harvest. The results demonstrated the efficiency of essential oil in controlling fungi. Pimentel et al. (2010) used the essential oil of Tanaecium nocturnum to control Aspergillus flavus being used by contact and fumigation. The essential oil from $500 \mathrm{ppm}$ inhibited the sporulation of the fungus.

Therefore, this work aimed to evaluate the effect of essential oils of M. spicata, M. arvensis and C. citriodora on the mycelial growth of Pythium sp.

\section{MATERIAL AND METHODS}

The present work was developed in the Phytopathology laboratory of the Federal Institute of Education, Science and Technology of Mato Grosso do Sul, located in the city of Nova Andradina - State of Mato Grosso do Sul, Brazil. For isolation, fragments of the intermediate region between the diseased area and the healthy area were disinfected with $70 \%$ alcohol for 30 seconds, $0.5 \%$ sodium hypochlorite for 2 minutes and washing the material in sterile distilled water for 1 minute 2 times, and then transferring he material to Petri dishes containing BDA culture medium (Potato-Dextrose-Agar) and incubated in BOD at a temperature of $25 \pm 2^{\circ} \mathrm{C}$ (ALFENAS, 2016). After mycelial growth, BDA discs were removed from the marginal region of the growing colony and transferred to another plate with BDA and incubated under the conditions already mentioned. The identification was carried out through observation of the morphological structures. The pure cultures were properly preserved in agar-water culture medium discs and placed in a refrigerator at an average temperature of $4^{\circ} \mathrm{C}$.

The essential oils of $C$. citriodora, $M$. spicata e $M$. arvensis were diluted in a $2 \%$ tween 20 solution, obtaining concentrations of $0,50,100,500$ and $1000 \mathrm{mg} \mathrm{ml}^{-1}$. Then $1 \mathrm{ml}$ of each dilution was added to $60 \mathrm{ml}$ of FDA medium, which was poured into three petri dishes. After solidification of the medium, a $5 \mathrm{~mm}$ diameter BDA disc containing fungal growth was placed in the center of each plate and incubated in B.O.D at $25 \pm 2^{\circ} \mathrm{C}$ in the dark. After 4 days of incubation, the diameter of the colonies was obtained by measuring in two diametrically opposite directions using a caliper. A completely randomized design was used, with a factorial scheme of three essential oils $(C$. citriodora, M. spicata and M. arvensis) x five concentrations (0, 50,100, 500 and $\left.1000 \mathrm{mg} \mathrm{ml}^{-1}\right)$. For each treatment, three repetitions were taken place. Through the results, the percentage of mycelial growth inhibition (PIC) was calculated. To calculate the PIC the following formula was used: $\mathrm{PIC}=($ control diameter - treatment diameter $) /($ control diameter $) \times 100$. 
Data were subjected to statistical analysis using the $\mathrm{R}$ software (version 4.0.5). The analysis of variance (ANOVA) followed by the $t$ test, were employed and the differences between individual means were deemed to be significant at $\mathrm{p}<0.05$.

\section{RESULTS AND DISCUSSION}

This is the first study in Brazil involving the use of essential oils of the species studied in order to control Pythium sp. The essential oils of C. citriodora and M. spicata, already at the concentration of $50 \mathrm{mg} \mathrm{ml}^{-1}$, exerted an inhibition of mycelial growth. C. citriodora being the one with the greatest inhibition (33.70\%) followed by M. spicata (21.48\%) and M. arvensis which had no inhibitory effect. At a concentration of $100 \mathrm{mg} \mathrm{ml}^{-1}$, the oil of $M$. arvens obtained greater inhibition (86.48\%), followed by C. citriodora (36.48\%) and M. spicata (31.60\%), which did not differ between them. Inhibition greater than $70 \%$ was observed at a concentration of $500 \mathrm{mg} \mathrm{ml}^{-1}$ for all essential oils studied, with no significant difference between them. Finally, the $100 \%$ inhibition of the mycelial growth of Pythium sp. was achieved at a concentration of $1000 \mathrm{mg} \mathrm{ml}^{-1}$ (Table 1 and Figure 1).

Table 1. Percentage of mycelial growth inhibition of Pythium sp. in the presence of the three essential oils in different concentrations, Nova Andradina, Mato Grosso do Sul State, Brazil, 2020.

\begin{tabular}{cccc}
\hline \multicolumn{4}{c}{ Percentage (\%) of mycelial growth inhibition (PIC) } \\
\hline $\begin{array}{c}\text { Concentration } \\
\left(\mathbf{m g ~ m l}^{-1}\right)\end{array}$ & Mentha spicata & Mentha arvensis & Corymbia citriodora \\
\hline 50 & $21.48 \mathrm{Bc}$ & $0.00 \mathrm{Cd}$ & $33.70 \mathrm{Ac}$ \\
100 & $31.66 \mathrm{Bc}$ & $57.41 \mathrm{Ac}$ & $36.48 \mathrm{Bc}$ \\
500 & $72.96 \mathrm{Cb}$ & $86,48 \mathrm{ABb}$ & $80.00 \mathrm{BCb}$ \\
1000 & $100 \mathrm{Aa}$ & $100 \mathrm{Aa}$ & $100 \mathrm{Aa}$ \\
\hline Witness & $0 \mathrm{Ad}$ & $0 \mathrm{Ad}$ & $0 \mathrm{Ad}$ \\
\hline CV\% & 15.11 & & \\
\hline
\end{tabular}

Vertical lowercase and horizontal uppercase letters do not differ significantly in the 5\% t-test. 


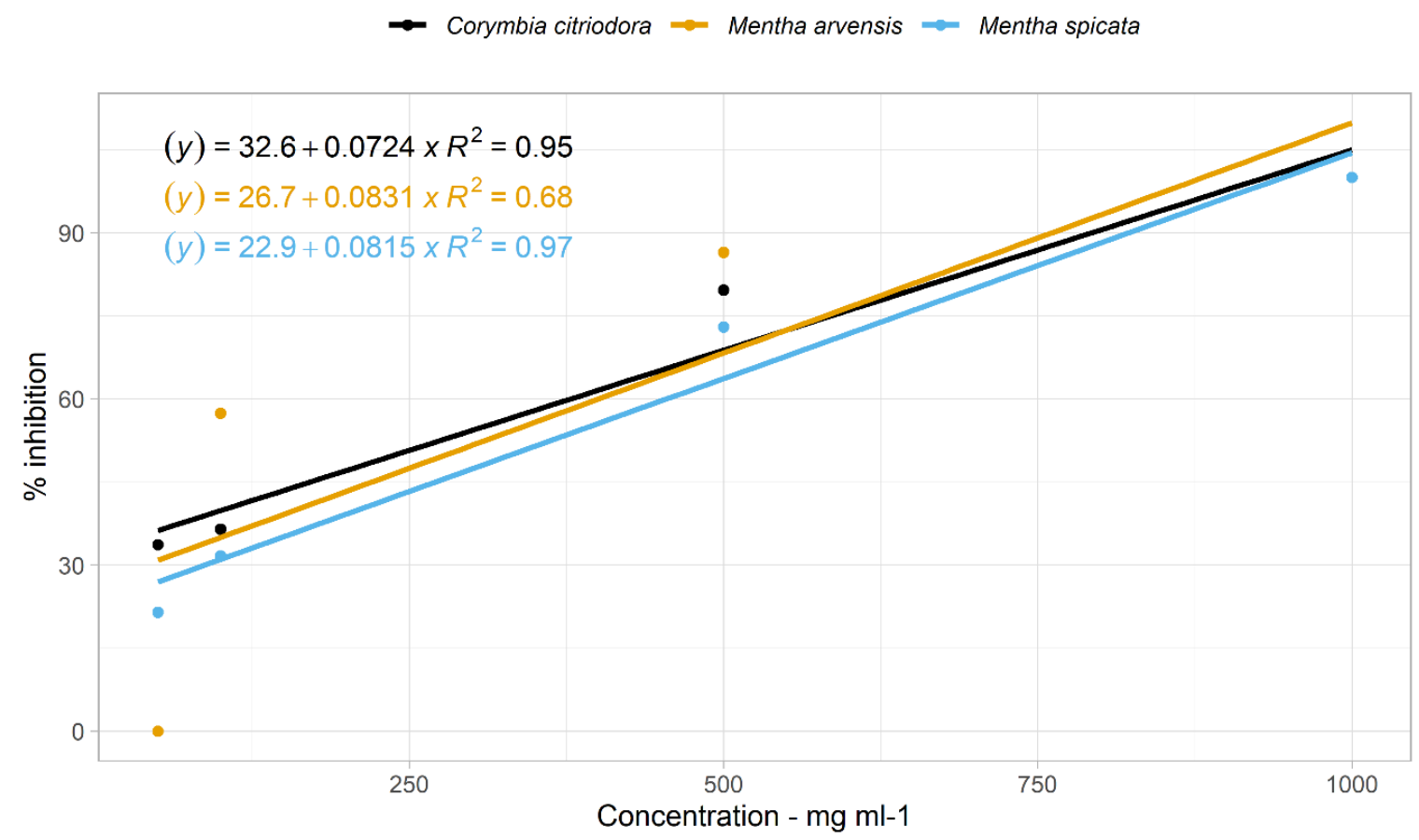

Figure 1. Representation of the percentage of mycelial growth inhibition of Pythium sp. in the presence of the three essential oils in different concentrations, Nova Andradina, Mato Grosso do Sul State, Brazil, 2020.

The essential oil of M. arvensis showed superior results at concentrations of 100 and 500 $\mathrm{mg} \mathrm{ml}^{-1}$, inhibiting mycelial growth by $57.41 \%$ and $86.48 \%$ respectively. Carnelossi et al. (2009) studied 4 oils, including $C$. citriodora and $M$. arvensis, in doses of 1, 5, 10, 15, 25, $50 \mu 1$ on anthracnose in papaya, caused by the fungus Colletotrichum gloeosporioides. In this study, they observed a $100 \%$ inhibition of the disease at a dose of $50 \mu \mathrm{L}$. It is suggested that this inhibition is related to menthol, which is the major compound of the essential oil of $M$. arvensis, since it has an antifungal effect reported in the literature (ROMERO et al., 2013).

When the essential oils were compared, there was a difference in the concentration of 50 $\mathrm{mg} \mathrm{ml}^{-1}$ of the essential oil of $C$. citriodora in relation to the other essential oils. Dias-Arieira et al. (2010) evaluated the essential oil of $C$. citriodora in the inhibition of mycelial growth of Colletotrichum acutatum, in concentrations of $0.25 ; 0.5 ; 1.0$ and $1.5 \%$. The authors found a $91.1 \%$ inhibition on the fungus at concentrations of 1.0 and $1.5 \%$. The effect may be related to the presence of the citronellar major component of the essential oil of $C$. citriodora, its antifungal effect being reported in the literature (OOTANI et al., 2016). 
Souza et al. (2018) studied the essential oil of Lippia alba, whose major compound is Lcarvone, the same component present in the essential oil of M. spicata in the control of Fusarium spp. and Rhizoctonia solani in vitro, using concentrations of $0.10 ; 0.25 ; 0.50 ; 0.75$ and $1.25 \mu 1 . \mathrm{ml}^{-}$

1 . The authors presented an average percentage of inhibition of $88.5 \%$. With this, it is possible to associate the inhibition effect presented in this work with the presence of the major compound Lcarvone in the tested essential oil.

\section{CONCLUSIONS}

The essential oils of $C$. citriodora, $M$. arvensis and $M$. spicata were efficient in inhibiting the mycelial growth of Pythium sp. The effect of essential oils on the growth of this phytopathogen shows that they can be used in the formulation of biofumigants for soil treatment for seedling production or in the field.

\section{REFERENCES}

AGRIOS, G. N. 2005. Plant pathology. San Diego: Elsevier Academic Press, 5. ed. 952p.

ALFENAS, A. C.; FERREIRA, F. A.; MAFIA, R. G.; GONÇALVES, R. C. 2016. Isolamento de Fungos fitopatogênicos. In: ALFENAS, A. C; MAFIA, R. G. (ed.) Métodos em Fitopatologia, Viçosa: UFV, p. 55-92.

CAMPANOLA, C.; BETTIOL, W. 2003. Panorama sobre o uso de agrotóxicos no Brasil. In: CAMPANOLA, C.; BETTIOL, W. (ed.) Métodos Alternativos de Controle Fitossanitário. Jaguariúna: Embrapa Meio Ambiente, p. 13-50.

CARNELOSSI, P. R.; SCHWAN-ESTRADA, K. R. F.; CRUZ, M. E. S.; ITAKO, A. T.; MESQUINI, R. M. 2009. Óleos essenciais no controle pós-colheita de Colletotrichum gloeosporioides em mamão. Revista Brasileira de Plantas Medicinais, Botucatu, v. 11, n. 4, p. 399-406.

DIAS-ARIEIRA, C. R.; FERREIRA, L. R.; ARIEIRA, J. O.; MIGUEL, E. G.; DONEGA, M. A.; RIBEIRO, R. C. F. 2010. Atividade do óleo de Eucalyptus citriodora e Azadirachta indica no controle de Colletotrichum acutatum em morangueiro. Summa Phytopathologica, Botucatu, v. 36, n. 3, p. 228-232.

EL OUADI, Y.; MANSSOURI, M.; BOUYANZER, A.; MAJIDI, L.; BENDAIF, H.; ELMSELLEM, H.; SHARIATI, M. A.; MELHAOUI, A.; HAMMOUTI, B. 2017. Essential oil composition and antifungal activity of Melissa officinalis originating from north-Est Morocco, against postharvest phytopathogenic fungi in apples. Microbial Pathogenesis, Holanda, v. 107, p. 321-326.

MEDEIROS, F. C. M.; GOUVEIA, F. N.; BIZZO, H. R.; VIEIRA, R. F.; DEL MENEZZI, C. H. S. 2016. Fungicidal activity of essential oils from Brazilian Cerrado species against wood decay fungi. International Biodeterioration \& Biodegradation, Amsterdam, v. 114, p. 87-93. 
OOTANI, M. A.; BRITO, D. R.; MACIEL, G. P. S.; LOPES, L. A.; AGUIAR, R. W. S. 2016. Efeito de óleos essenciais e composto citronelal sobre a micoflora de sementes de feijão armazenadas. Revista Verde, Pombal, v. 11, n. 1, p. 49-56.

PIMENTEL, F. A.; CARDOSO, M. G.; BATISTA, L. R.; GUIMARÃES, L. G. L.; SILVA, D. M. 2010. Ação fungitóxica do óleo essencial de Tanaecium nocturnum (Barb. Rodr.) Bur. e K. Shum sobre o Aspergillus flavus isolado da castanha-do-Brasil (Bertholletia excelsa). Acta Amazonica, Manaus, v. 40, n. 1, p. 213-220.

ROMERO, A. L.; OLIVEIRA, R. R.; ROMERO, R. B.; ALMEIDA, A. L.; DINIZ, S. P. S. S.; VIDA, J. B. 2013. Efeito de monoterpenos naturais no crescimento micelial e germinação de conídios de Corynespora cassiicola. Pesquisa Agropecuária Pernambucana, Recife, v. 18, n. 1, p. 3-7.

SOUZA, B. C. M.; CASTRO, S. P.; LOURIDO, K. A.; CHIARA, D.; CASTRO, K. C. F.; LUSTOSA, D. C. 2018. Óleo essencial de erva-cidreira sobre fitopatógenos de espécies florestais e agrícolas. Agrossistemas, Belém, v. 10, n. 1, p. 206-215.

SOUSA, R. M. S.; SERRA, I. M. R. S.; MELO, T. A. 2012. Efeito de óleos essenciais como alternativa no controle de Colletotrichum gloeosporioides, em pimenta. Summa Phytopathologica, Botucatu, v. 38, n. 1, p. 42-47.

TRANCOSO, M. D. 2013. Projeto Óleos Essenciais: extração, importância e aplicações no cotidiano. Revista Práxis, Rio de Janeiro, v. 5, n. 9, p. 89-96.

ZAMBOLIM, L.; JESUS JÚNIOR, W. C. 2012. Controle físico de doenças de plantas. In: ZAMBOLIM, L.; JESUS JÚNIOR, W. C.; RODRIGUES, F. A. (ed.) O essencial da fitopatologia: controle de doenças de plantas. Viçosa: UFV, p. 303-334. 